\title{
Efektivitas Media Pembelajaran Aplikasi Quizizz Secara Daring Terhadap Perkembangan Kognitif Siswa
}

\section{Issrina Dwika Hidayati ${ }^{*}$, Aslam ${ }^{2}$}

\author{
1,2 Universitas Muhammadiyah Prof. Dr. Hamka, Jakarta, Indonesia
}

\section{ART ICLE IN F O}

\section{Article history:}

Received April 22, 2021

Revised April 30, 2021

Accepted July 12, 2021

Available online July 25, 2021

Kata Kunci:

Media Pembelajaran, Quizizz,

Perkembangan Kognitif

Keywords:

Learning Media, Quizizz, Cognitive Development

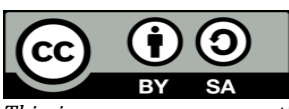

This is an open access article under the CC BY-SA license.

Copyright (C) 2021 by Author.

Published by Universitas Pendidikan Ganesha.

\begin{abstract}
A B S T R A K
Penelitian ini didasari oleh penggunakan perangkat pembelajaran online interaktif yang kurang maksimal dan efektif untuk membantu siswa meningkatkan pengetahuannya sehingga membuat siswa jenuh dan malas. Penelitian ini ditujukan untuk menganalisis efektivitas dari media pembelajaran menggunakan aplikasi Quizizz terhadap perkembangan kognitif siswa kelas 3. Mempergunakan kuantitatif bermetode True Experimental mengambil Pretest - Posttest Control Group Design. Teknik pengambilan sample mempergunakan Simple Random Sampling, agar diperoleh sebanyak 56 siswa. Jenis instrumen penelitian menggunakan tes berupa pilihan ganda. Teknik analisis data yang dipergunakan statistik melalui aplikasi spss 27 dengan rumus mean, median, modus, standar deviasi, tes normalitas kolmogorovsmirnov, homogenitas levene, paired sample t-test, dan n-gain score. Hipotesis penelitian menyatakan terdapat pengaruh yang diperoleh dari perlakuan menggunakan Quizizz, yaitu penaikan hasil siswa dalam kelas eksperimen dengan unggul dari nilai sebelumnya. Dibandingkan kelas kontrol yang hanya menggunakan Zoom Meeting. Berdasarkan n-gain score menyatakan nilai mean kelas eksperimen sejumlah 56,3363 atau 56\% yang termasuk dalam kategori cukup efektif. Untuk $n$ gain score nilai mean kelas kontrol berjumlah 42,3541 atau 42\% yang berarti kurang efektif. Dengan adanya hasil tersebut dapat disimpulkan bahwa media pembelajaran aplikasi Quizizz secara daring cukup efektif dipergunakan untuk perkembangan kognitif siswa dalam mata pelajaran Bahasa Indonesia kelas 3.
\end{abstract}

\section{A B S T R A C T}

This research is based on using interactive online learning tools that are less maximal and effective to help students improve their knowledge so as to make students saturated and lazy. This study is intended to analyze the effectiveness of learning media using Quizizz application to the cognitive development of grade 3 students. Using quantitative method True Experimental take Pretest - Posttest Control Group Design. Sampling techniques use Simple Random Sampling, to be obtained by as many as 56 students. This type of research instrument uses multiple choice tests. Data analysis techniques used statistics through application spss 27 with the formula mean, median, mode, standard deviation, kolmogorovsmirnov normality test, levene homogeneity, paired sample t-test, and n-gain score. The research hypothesis states that there is an influence gained from the treatment using Quizizz, which is the increase in student outcomes in experimental classes with superiority from previous grades. Compared to the control class that only uses Zoom Meeting. Based on the ngain score, the mean value of the experimental class of 56.3363 or $56 \%$ that falls into the category is quite effective. For n-gain score the mean value of the control class amounts to 42.3541 or $42 \%$ which means less effective. With these results, it can be concluded that the learning media of Quizizz application online is quite effectively used for the cognitive development of students in the subjects of Bahasa Indonesia grade 3.

\section{PENDAHULUAN}

Pada abad ke-21, kemajuan di bidang teknologi semakin berkembang pesat. Pengaruh dari berkembangnya teknologi, sangat dirasakan sekali manfaatnya khususnya ketika seluruh negeri di dunia dilanda fenoma wabah penyakit covid-19 (Herliandry et al., 2020; Wilson, 2020). Dalam sistem pendidikan yang biasanya dijalankan dengan tatap muka, namun sekarang dilaksanakan dengan sistem daring untuk mencegah terjadinya penyebaran virus (Husna, 2020; Wijayanti et al., 2021). Berhubungan dengan itu, para guru harus lebih inovatif dan kreatif lagi untuk dalam menggunakan media pembelajaran berbasis online sebagai perantara pembelajaran online (Citra \& Rosy, 2020; Dewi, 2020). Perangkat pembelajaran online berlaku sebagai semacam perangkat yang bisa dipergunakan dengan mudah terlebih pembelajaran jarak jauh. Media pembelajaran online ini bersifat mandiri dan membiarkan penggunanya untuk mempengaruhi atau mengubah sumber yang diakses yang dapat memberikan kemudahan dalam menyampaikan informasi, meng-update informasi, memberikan lebih banyak pengalaman dalam belajar (Efriani et al., 2020; Oktarina, 2020). Pada penggunaan media pembelajaran interaktif dapat 
meningkatkan keefektifan pembelajaran, menjadi lebih mudah, menyenangkan, dan menarik bagi siswa, didukung dengan data dan pendekatan pembelajaran yang diharapkan secara teoritis dan praktis (Aslam, 2020; Rahmat, 2017; Wahyuningtyas \& Sulasmono, 2020). Bahasa Indonesia sebagai mata pelajaran wajib di kelas 3 SD mempunyai kekhasannya tersendiri yang dirasakan oleh para siswa dalam menyerap materi yang diterangkan guru. Dibutuhkannya penjelasan ekstra dan tertata dari guru dalam menjelaskan materi, namun karena penggunaan media pembelajaran yang dirasa kurang selaras serta siswa yang sudah mulai merasa bosan dengan pembelajaran di rumah membuat siswa tidak dapat mengerjakan tugasnya dengan baik. Bahasa sendiri memiliki peranan utama untuk perkembangan pengetahuan, sosial, emosional siswa, dan juga faktor pendorong kesuksesan siswa dalam menyelami seluruh sektor pelajaran (Khair, 2018; Priatna \& Setyarini, 2019). Mata pelajaran Bahasa Indonesia ditujukan agar mampu mempengaruhi peningkatan kemampuan siswa dalam semua aspek. Tidak dapat dipungkiri lagi jika pembelajaran Bahasa Indonesia sangatlah penting bagi para siswa (Putri Ningrat et al., 2018; Rahmat, 2017). Sebab itu para guru harus menanamkan rasa cinta akan mata pelajaran Bahasa Indonesia kepada siswanya yang dapat dilakukan dengan membuat pembelajaran Bahasa Indonesia menjadi menyenangkan dibantu dengan penerapan media pembelajaran yang tepat dengan kebutuhan materi ajar dan kondisi siswa.

Berdasarkan hasil analisis awal yang dilakukan secara wawancara dengan koordinator guru di SD Islam Nurul Hidayah Depok khususnya koordinator di kelas 3, pembelajaran menggunakan media online berbasis Zoom Meeting baru saja dilaksanakan ketika semester genap tahun ajaran 2020/2021. Di semester ganjil, guru hanya menggunakan media online WhatsApp Group saja. Meskipun perkembangan teknologi, khususnya dalam mengembangkan media pembelajaran dirasa sudah mencukupi untuk mendukung kegiatan pembelajaran siswa di rumah selama masa pandemi. Ternyata dalam penggunaannya dirasa kurang efektif dan tidak maksimal sehingga tidak dapat menutup kemungkinan timbulnya kejenuhan siswa selama belajar dari rumah. Terlebih dalam situasi dan kondisi saat ini, dimana siswa sudah sangat merasa jenuh yang mengakibatkan mereka menjadi malas dalam mengerjakan tugas seperti yang dikemukakan (Maulidina \& Bhakti, 2020; Putria et al., 2020; Satrianingrum \& Prasetyo, 2020) dalam studi yang ditelitinya. Hal tersebut dapat berdampak buruk pada kemajuan intelektual dan pemahaman siswa terhadap materi yang diberikan oleh guru. Pengkondisian kelas yang dapat dilakukan oleh guru dapat berupa penggunaan media pembelajaran yang sesuai dengan materi ajar sangatlah mempengaruhi kemampuan daya tangkap siswa terhadap ilmu pengetahuan yang diberikan guru. Bila menggunakan media pembelajaran yang selaras dengan materinya, siswa dengan mudah menangkap materi yang telah dipaparkan oleh guru dan tujuan dari pembelajaran tersebut bisa tercapai (Hakim, 2018; Istiqlal, 2018). Salah satu solusi mengatasi masalah tersebut adalah dengan pengunaan media pembelajaran interaktif Quizizz.

Penggunaan media pembelajaran interaktif Quizizz berdampak positif bagi guru dan siswa. Guru dimudahkan dengan bantuan penggunaan Quizizz dari banyaknya materi yang sudah ada dalam aplikasi tersebut, dalam menyampaikan materi pembelajaran, mengondisikan siswa dalam kelas, dan meningkatkan motivasi siswa dalam belajar. Bagi siswa, dalam Quizizz terdapat beberapa fitur yang membuat motivasi siswa menjadi meningkat sehingga dianggap sebagai media pembelajaran yang menarik, karena memberikan suasana baru, mempermudah siswa dalam memahami materi pembelajaran (Mulyati \& Evendi, 2020; Wahyudi et al., 2020). Dengan menambahkan unsur permainan dalam kegiatan belajar-mengajar dimana siswa dapat berperan aktif dapat membantu meningkatkan perkembangan kognitif siswa. Perkembangan kognitif pada siswa sebagian besar bergantung kepada sejauh mana siswa tersebut aktif dalam bersosialisasi dengan lingkungan sekitarnya. Semakin meningkatnya keaktifan siswa diharapkan semakin besar pula hasil yang dapat ia peroleh (Khaulani et al., 2020; Mitasari, 2018). Perkembangan kognitif ialah satu dari semua aspek perkembangan manusia bersangkutan dengan pengetahuan, dimana keseluruhan proses psikologis bersangkutan dengan bagaimana cara individu belajar dan memahami lingkungan sekitarnya. Hasil belajar yang didapatkan oleh siswa termasuk ke dalam aspek kognitif dimana menegaskan pada bagaimana proses untuk menjadikan yang terbaik dalam kemampuan aspek rasional yang dimiliki siswa (Hanafi \& Sumitro, 2020; Sutarto, 2017). Saat ini, sudah banyak media pembelajaran yang dapat memancing keaktifan siswa selama kelas berlangsung sehingga siswa mampu mencapai aspek atau prestasi belajarnya (Angreany \& Saud, 2017; Susilo, 2020). Salah satunya adalah dengan menggunakan media pembelajaran berbasis games kuis, yang dinamakan Quizizz. Games Quizizz sebagai aplikasi pembelajaran berbasis games, menghadirkan kegiatan multi-permainan di dalam ruangan kelas serta menjadikan ruang kelas sebagai latihan interaktif pun menyenangkan, membuat siswa dapat berkompetisi antar siswa lain sehingga memotivasi siswa dalam belajar, agar meningkatkan hasil belajar. Ini membantu siswa untuk meningkatkan apresiasi kuis, upaya belajar, motivasi belajar, keterlibatan kegiatan dan prestasi akademik sehingga siswa dapat mengalami perkembangan kognitifnya dengan baik sesuai dalam penelitian yang dilakukan (Basuki \& Hidayati, 2019; Salsabila et al., 2020; Wibawa et al., 2019). Penelitian terdahulu Menggunakan media pembelajaran 
selama kegiatan belajar-mengajar juga diharapkan dapat membantu menaikkan self motivated learning dan self regulated learning pada siswa sehingga mereka dapat menggunakannya untuk mengontrol perilaku serta sebagai bekal untuk membangun pengetahuan (kognitifnya) yang telah dimilikinya lebih pesat lagi.

Dengan berpegang pada pendapat para ahli di atas dan beberapa masalah yang dikemukakan, peneliti memberikan solusi dengan peranan perangkat pembelajaran berlandas games Quizizz dapat mendorong siswa untuk aktif serta turut andil selama aktifitas di kelas. Fokus serta motivasi siswa untuk memahami materi menjadi meningkat, hal tersebut diharapkan dapat berpengaruh pada bertambahnya aspek kognitif yang diterima siswa selama kegiatan pembelajaran. Kegiatan pembelajaran selama pandemi juga tidak akan terasa membosankan, karena suasana belajar menjadi lebih menyenangkan sehingga dapat membantu siswa untuk mencapai prestasi belajarnya. Sehingga tujuan dalam penelitian ini agar dapat menganalisis sejauh mana efektivitas yang diberikan media pembelajaran aplikasi quizizz secara daring terhadap perkembangan kognitif siswa berkaitan dengan mata pelajaran khususnya Bahasa Indonesia di kelas 3 Sekolah Dasar.

\section{METODE}

Proses penelitian ini memakai kuantitatif dan mengambil metode True Experimental Design yang dilakukan secara sistematis dengan memberikan treatment atau perlakuan tertentu pada kelompok eksperimen. Desain yang dimanfaatkan ialah Pretest - Posttest Control Group Design yang ditunjukan pada gambar 1. Diberikan perlakuan setelah dilaksanakan pre-test, serta post-test setelah mendapatkan perlakuan berupa Quizizz dan Zoom Meeting bagi kelas eksperimen. Sedangkan kelas kontrol setelah pretest, perlakuan melalui Zoom Meeting, diakhiri dengan post-test. Subjek penelitian ini Seluruh siswa kelas 3 di SD Islam Nurul Hidayah Depok yang tersusun dari 3 kelas yang mencapai jumlah 82 anak. Teknik pengambilan sampel mempergunakan cara acak atau Simple Random Sampling. Sehingga dapat dihasilkan sampel penelitian ini adalah kelas 3A dan 3B di SD Islam Nurul Hidayah Depok Tahun Ajaran 2020/2021 yang berjumlah 56 anak. Kelas 3A menjadi kelas eksperimen serta kelas 3B menjadi kelas kontrol.

\begin{tabular}{|llll|}
\hline $\mathrm{E}$ & $Q_{1}$ & $\mathrm{X}$ & $Q_{2}$ \\
$\mathrm{~K}$ & $Q_{3}$ & & $Q_{4}$ \\
\hline
\end{tabular}

Gambar 1. Desain Penelitian

Penelitian mempergunakan teknik pengambilan data pilihan ganda. Dipergunakan sebagai alat untuk mengukur dan mengetahui apakah adanya pengaruh atau tidak terhadap perkembangan kognitif siswa mata pelajaran Bahasa Indonesia dengan memanfaatkan media pembelajaran berbasis kuis. Jenis tes yang dipergunakan berupa tes pilihan ganda dengan opsi a, b, dan c. Dengan skor "1" jikalau siswa dapat menjawab dengan benar, serta skor "0" jikalau siswa menjawab dengan salah. Kisi-kisi penelitian di tunjukkan pada Tabel 1 . Sebelum dilakukannya penelitian, dilaksanakan uji coba instrumen pada uji valid, reliabel, tingkat kesukaran, serta daya pembeda. Berdasar hasil perhitungan mencoba instrumen dinyatakan valid sebanyak 30 soal. Hasil validitas lebih lengkap ditunjukan pada tabel 2. Teknik analisis data yang dipergunakan statistik pada rumus mean, median, modus, standar deviasi, tes normalitas, homogenitas, t-test, dan $n$-gain score.

Tabel 1. Kisi-Kisi Instrumen Uji Validitas

\begin{tabular}{|c|c|c|c|c|c|}
\hline \multirow{2}{*}{ No } & \multirow{2}{*}{ Indikator } & \multicolumn{3}{|c|}{ Nomor Butir Soal } & \multirow{2}{*}{$\begin{array}{l}\text { Jumlah } \\
\text { Butir Soal }\end{array}$} \\
\hline & & C1 & $\mathrm{C} 2$ & C3 & \\
\hline 1 & $\begin{array}{l}\text { Mengidentifikasi ide pokok dari teks dengan } \\
\text { tepat. }\end{array}$ & 11,13 & $\begin{array}{l}1,2,9,21 \\
27,33\end{array}$ & $\begin{array}{c}36 \\
38,40\end{array}$ & 11 \\
\hline 2 & $\begin{array}{l}\text { Mengidentifikasi kalimat utama tiap paragraf } \\
\text { dari suatu bacaan dengan tepat. }\end{array}$ & 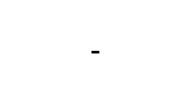 & $25,26,28$ & $\begin{array}{l}35, \\
37,39\end{array}$ & 6 \\
\hline 3 & $\begin{array}{l}\text { Menemukan kosakata baru tentang } \\
\text { perkembangan teknologi komunikasi dengan } \\
\text { benar. }\end{array}$ & $\begin{array}{l}3,5,10,15 \\
20,29,30 \\
31,32\end{array}$ & $\begin{array}{l}7,17,22 \\
23,24,34\end{array}$ & - & 15 \\
\hline 4 & $\begin{array}{l}\text { Menggunakan kosakata tersebut dalam } \\
\text { sebuah kalimat dengan tepat. }\end{array}$ & $\begin{array}{c}4,6,12,14 \\
18\end{array}$ & 8,16 & - & 7 \\
\hline
\end{tabular}


Tabel 2. Validitas Butir Soal

\begin{tabular}{ccccc}
\hline No & Kriteria & Nomor Soal & Jumlah & Persentase (\%) \\
\hline \multirow{2}{*}{1} & Valid & $1,3,4,5,7,8,9,11,13,14,16,17,19$, & \\
& $20,22,23,24,25,27,28,29,30,32,33$, & 30 & $75 \%$ \\
2 & Tidak Valid & $2,6,10,12,15,18,21,26,31,34$ & 10 & $25 \%$ \\
\hline
\end{tabular}

\section{HASIL DAN PEMBAHASAN}

Hasil

Uji normalitas merupakan suatu cara untuk mencari tau hasil perkembangan kognitif Bahasa Indonesia siswa yang mempergunakan media pembelajaran Aplikasi Quizizz berdistribusi normal atau sebaliknya, penghitungan ini dilakukan melalui uji normalitas dengan taraf yang signifikan $(\alpha=0,05)$. Hasilnya dapat diperhatikan dalam tabel 5 . Hasil uji normalitas dapat dianalisis dengan membandingkan nilai (sig.) terbesar dengan tingkat signifikan $(\alpha=0,05)$. Bila nilai (sig.) $>(\alpha=0,05)$ berhak diketahui kalau data yang disebut di atas berdistribusi normal. Berdasar tabel 3, dapat ditemukan nilai (sig.) kelas eksperimen serta nilai (sig.) kelas kontrol memiliki nilai yang tinggi dari 0,05. Didapati hasil dalam kedua kelas berdistribusi normal. Uji selanjutnya adalh Uji homogenitas. Penghitungan uji homogenitas taraf signifikan $\alpha=0,05$. Dalam tipe pengujian berikut: bila nilai (sig.) lebih unggul dibandingkan tingkat signifikan $(0,05)$ karenanya data tersebut disimpulkan homogen. Hasil penghitungan pada kedua kelas menyatakan nilai (sig.) 0,907 $>0,05$. Berhak diartikan data tersebut bersifat homogen. Jika hasil bernilai (sig.) $<0,05$ alhasil data tersebut tidak homogen.

Tabel 3. Hasil Uji Normalitas Pre-Test dan Post-Test

\begin{tabular}{clccc}
\hline & \multicolumn{1}{c}{ Kelas } & \multicolumn{3}{c}{ Kolmogorov-Smirnov } \\
\cline { 3 - 5 } & & Statistik & df & Sig. \\
\hline \multirow{2}{*}{ Hasil Belajar } & Pre-Test Kelas Eksperimen (3A) & 0,153 & 30 & 0,070 \\
Bahasa & Post-Test Kelas Eksperimen (3A) & 0,117 & 30 & 0,200 \\
Indonesia & Pre-Test Kelas Kontrol (3B) & 0,164 & 26 & 0,069 \\
& Post-Test Kelas Kontrol (3B) & 0,133 & 26 & 0,200 \\
\hline
\end{tabular}

Uji tipe paired sample $t$-test difungsikan sebagai penguji hipotesis kenaikan nilai pre-test dan posttest bagi kelas diberi treatment Quizizz dan kelas non-treatment. Hasil menunjukkan kemampuan kognitif memperoleh Sig. two-sided $p$ di bawah 0,05, yakni 0,001 dimana terdapat ketidaksamaan mean hasil pretest dan post-test memakai perangkat pembelajaran aplikasi Quizizz di kelas eksperimen dan perangkat pembelajaran aplikasi Zoom Meeting di kelas kontrol. Artinya, terdapat pengaruh dari penggunaan media pembelajaran aplikasi Quizizz. Jika dilihat melalui nilai t, dapat ditemukan bahwa nilai t hitung di kelas eksperimen dan kontrol menghasilkan nilai negatif. Ini disebabkan oleh nilai mean hasil belajar pre-test lebih kecil daripada post-test. Dalam masalah seperti ini t hitung negatif dapat memiliki arti positif. Ditemukan hasil $t$ hitung unggul dari $t$ tabel, kelas eksperimen $t$ hitung 7,995 $>\mathrm{t}$ tabel 2,048 dan di kelas kontrol t hitung 7,594 > 2,064 sehingga disimpulkan Ho ditolak dan Ha dapat diterima.

Hasil uji efektivitas dan menyesuaikan dengan tabel kriteria $n$-gain score maka diperoleh mean kelas eksperimen sebesar 56,3363 atau 56\% dan dinyatakan pemakaian aplikasi Quizizz memiliki tingkat yang cukup efektif terhadap perkembangan kognitif siswa dibandingkan dengan hasil sebelum diberikan perlakuan. Sedangkan pada kelas kontrol, mean diperoleh sebesar 42,3541 atau $42 \%$ atau dinyatakan kurang efektif dalam menggunakan aplikasi Zoom Meeting terhadap perkembangan kognitif siswa. Berdasarkan hasil penelitian di atas, media pembelajaran aplikasi Quizizz yang berbasis games sangat tepat dan efektif digunakan dalam kegiatan pembelajaran secara daring sehingga sesuai dijadikan solusi dari permasalahan yang timbul pada siswa. Dikarenakan rasa jenuh dan malas akibat dari lamanya siswa belajar secara daring, membuat mereka kehilangan motivasi dan minat untuk aktif dan belajar lebih giat. Hal tersebut dirasakan oleh siswa di kelas rendah, dengan penggunaan media pembelajaran berunsur permainan dapat merangsang siswa untuk turut andil selama kegiatan pembelajaran berlangsung. Siswa menjadi lebih antusias dan semangat, sehingga dapat menghilangkan rasa jenuh dan malas selama pembelajaran dari rumah karena memberikan perasaan menyenangkan, nyaman, dan humor di dalam pembelajaran. Sehingga kecerdasan intelektual mereka dapat berkembang dengan baik.

Bila dihubungkan dan didukung dengan penelitian sebelumnya, menyatakan bahwa penggunaan media pembelajaran aplikasi Quizizz dapat meningkatkan beberapa aspek dalam diri siswa. Tidak hanya bagi siswa, guru pun juga merasakan manfaat positif yang dihadirkan dalam aplikasi tersebut. Inovasi 
yang diberikan dengan penggunaan aplikasi Quizizz dalam pembelajaran online selama pandemi covid-19, dirasa sangat memudahkan selama kegiatan pembelajaran berlangsung. Kegiatan pembelajaran berbasis games Quizizz juga berpengaruh signifikan dan efektif digunakan dalam peningkatan hasil belajar siswa. Peningkatan aspek keaktifan, motivasi belajar, sangat membantu siswa mengaktifkan daya tangkap atau pemahaman mereka. Peserta didik yang dengan mudah dan antusias dalam mengikuti proses pembelajaran akan berdampak pada hasil belajarnya. Pemahaman siswa dalam materi pembelajaran menjadi lebih tinggi, dan mengasah siswa untuk dapat berfikir kritis atas materi yang diberikan oleh guru. Hal tersebut memberikan peluang bagi perkembangan kognitif siswa menjadi lebih tinggi. Selain itu, penggunaan media pembelajaran aplikasi Quizizz dapat memberikan respon aktif antar siswa dalam bersaing sehingga dapat memicu siswa untuk belajar lebih baik. (Citra \& Rosy, 2020; Mitasari, 2018; Mulyati \& Evendi, 2020; Puspitorini et al., 2014; Wijayanti et al., 2021). Perbedaan yang terdapat dalam beberapa penelitian sebelumnya, ada pada subjek penelitian. Subjek dari penelitian terdahulu adalah siswa di kelas tinggi sehingga daya tangkap mereka lebih mudah dalam menggunakan dan mengoperasikan aplikasi Quizizz. Sedangkan dalam penelitian ini, subjeknya adalah siswa di kelas rendah yang masih membutuhkan bimbingan dan pendampingan dari orang tua.

Maka kontribusi dalam penelitian ini ialah dengan memberikan solusi pembelajaran berupa media pembelajaran online berbasis games Quizizz yang sebelumnya belum pernah digunakan. Sehingga dapat menambah ilmu dan wawasan guru ketika proses pembelajaran berlangsung menjadi lebih efektif dan efisien, serta menjadikan kelas lebih menyenangkan. Adapun implikasi dari penelitian ini selain membuat suasana pembelajaran menjadi menyenangkan dan aktif, guru dimudahkan dalam mengevaluasi pemahaman siswa terhadap materi yang diberikan. Siswa juga dapat melatih dirinya dengan menjawab kuis secara beragam yang sudah tersedia di aplikasi tersebut. Selain itu, aplikasi Quizizz dapat dijadikan bank soal oleh guru dalam melatih kemampuan intelektual siswa sehingga mendukung perkembangan kognitifnya. Tentunya terdapat keterbatasan dalam pelaksanaan penelitian ini ialah guru tidak bisa mengontrol dan membimbing siswa yang kesulitan dalam mengoperasikan aplikasi Quizizz secara tatap muka. Hal tersebut dikarenakan beberapa siswa tidak di dampingi oleh orang tua nya, dan beberapa siswa masih ada yang belum memahami cara penggunaan aplikasi Quizizz. Sehingga jauh-jauh hari sebelum dilaksanakannya pembelajaran, guru haruslah menjelaskan dan menerangkan secara rinci mengenai cara penggunaan aplikasi Quizizz kepada orang tua siswa agar kegiatan pembelajaran dapat terlaksana secara efektif dan tujuan dari pembelajaran juga dapat tersampaikan dengan baik. Sedangkan kelebihan dalam penelitian ini ialah analisis penelitian berupa angka sehingga hasil analisisnya lebih akurat tanpa adanya unsur subjektivtas. Hasil analisis penelitian ini meliputi tabel angka sehingga lebih mudah dipahami dan langsung mengarah pada satu inti dari kesimpulan sehingga dapat memudahkan bagi yang membacanya.

\section{SIMPULAN}

Pada masa pandemi banyak sekali ditemukan kesulitan-kesulitan dalam proses pembelajaran yang dirasakan oleh guru dan siswa. Hilangnya motivasi belajar membuat siswa merasa jenuh dan malas mengerjakan tugas yang diberikan sehingga siswa mengalami perkembangan kognitif dengan baik. Namun dengan penggunaan media pembelajaran berbasis games yang diberikan oleh guru sangatlah tepat untuk permasalahan yang terjadi pada siswa saat pembelajaran di rumah. Media aplikasi Quizizz yang memberikan banyak fitur menyenangkan bagi siswa karena mempermudah pembelajaran jarak jauh. Sehingga sangatlah efektif digunakan guru untuk mengetahui peningkatan perkembangan kognitif siswa. Selama masa pandemi berlangsung, penggunaan media pembelajaran online menjadi satu-satunya solusi yang dapat diterapkan selama kegiatan belajar-mengajar. Hadirnya bermacam-macam media pembelajaran online sangatlah memudahkan guru untuk menyampaikan materi yang akan diajarkan kepada siswanya.

\section{DAFTAR PUSTAKA}

Alam, S., Japar, M., \& Asnur, M. N. A. (2019). Pengembangan Instrumen Tes Siswa Tingkat Sekolah Dasar di Kabupaten Kuningan. Qalam: Jurnal Ilmu Kependidikan, 8(1), 59. https://doi.org/10.33506/jq.v8i1.389.

Angreany, F., \& Saud, S. (2017). Keefektifan Media Pembelajaran Flashcard Dalam Keterampilan Menulis Karangan Sederhana Bahasa Jerman Siswa Kelas Xi Ipa Sma Negeri 9 Makassar. Eralingua: Jurnal Pendidikan Bahasa Asing Dan Sastra, 1(2), 138-146. https://doi.org/10.26858/eralingua.v1i2.4410.

Arifin, M. (2018). Pengaruh Media Pembelajaran Mind Mapping terhadap Hasil Belajar Kognitif dan Psikomotorik IPA Siswa Kelas IV SD Negeri 01 Kandangmas. JGK (Jurnal Guru Kita), 2(September), 31-38. /https://doi.org/10.24114/jgk.v2i4.13573. 
Aslam, dkk. (2020). Internet User Behavior and Social Media in Learning. Atlantis Press, 526(Icream 2020), 50-55. https://dx.doi.org/10.2991/assehr.k.210212.010.

Basuki, Y., \& Hidayati, Y. (2019). Kahoot! or Quizizz: the Students' Perspectives. STKIP PGRI Trenggalek. https://doi.org/10.4108/eai.27-4-2019.2285331.

Citra, C. A., \& Rosy, B. (2020). Keefektifan Penggunaan Media Pembelajaran Berbasis Game Edukasi Quizizz Terhadap Hasil Belajar Teknologi Perkantoran Siswa Kelas X SMK Ketintang Surabaya. Jurnal Pendidikan Administrasi Perkantoran (JPAP), 8, 261-272. https://journal.unesa.ac.id/index.php/jpap/article/view/8242/4081.

Depdikbud. (2018). Silabus Kelas 3 Tema 7. Kementerian Pendidikan dan Kebudayaan.

Dewi, W. A. F. (2020). Dampak COVID-19 terhadap Implementasi Pembelajaran Daring di Sekolah Dasar. Edukatif: Jurnal Ilmu Pendidikan, 2(1), 55-61. https://doi.org/10.31004/edukatif.v2i1.89.

Efriani, E., Dewantara, J. A., \& Afandi, A. (2020). Pemanfaatan Aplikasi Discord Sebagai Media Pembelajaran Online. Jurnal Teknologi Informasi Dan Pendidikan, 13(1), 61-65. https://doi.org/10.24036/tip.v13i1.283.

Hakim, L. (2018). Pengembangan Media Pembelajaran Pai Berbasis Augmented Reality. Lentera Pendidikan: Jurnal Ilmu Tarbiyah Dan Keguruan, 21(1), 59-72. https://doi.org/10.24252/lp.2018v21n1i6.

Hanafi, I., \& Sumitro, E. A. (2020). Perkembangan Kognitif Menurut Jean Piaget Dan Implikasinya Dalam Pembelajaran. Alpen: Jurnal Pendidikan Dasar, 3(2). https://doi.org/10.24929/alpen.v3i2.30.

Herliandry, L. D., Nurhasanah, N., Suban, M. E., \& Kuswanto, H. (2020). Pembelajaran Pada Masa Pandemi Covid-19. JTP - Jurnal Teknologi Pendidikan, 22(1), 65-70. https://doi.org/10.21009/jtp.v22i1.15286.

Husna, R. (2020). Efektivitas Pembelajaran Turunan Pada Masa Pandemi Covid-19 Melalui Media Mobile Learning Ditinjau Dari Hasil Belajar Mahasiswa. Numeracy, 7(2), 324-333. https://doi.org/10.46244/numeracy.v7i2.1187.

Istiqlal, A. (2018). Manfaat Media Pembelajaran Dalam Proses Belajar Dan Mengajar Mahasiswa Di Perguruan Tinggi. Jurnal Kepemimpinan Dan Pengurusan Sekolah, 3(2), 139-144. http://dx.doi.org/10.34125/kp.v3i2.264.

Khair, U. (2018). Pembelajaran Bahasa Indonesia dan Sastra (BASASTRA) di SD dan MI. AR-RIAYAH : Jurnal Pendidikan Dasar, 2(1), 81. https://doi.org/10.29240/jpd.v2i1.261.

Khaulani, F., S, N., \& Irdamurni, I. (2020). Fase Dan Tugas Perkembangan Anak Sekolah Dasar. Jurnal Ilmiah Pendidikan Dasar, 7(1), 51. https://doi.org/10.30659/pendas.7.1.51-59.

Maulidina, S., \& Bhakti, Y. B. (2020). Pengaruh Media Pembelajaran Online Dalam Pemahaman Dan Minat Belajar Siswa Pada Konsep Pelajaran Fisika. ORBITA: Jurnal Kajian, Inovasi Dan Aplikasi Pendidikan Fisika, 6(2), 248. https://doi.org/10.31764/orbita.v6i2.2592.

Mitasari, N. R. (2018). Model Pembelajaran Edutaniment Terhadap Perkembangan Kognitif Siswa Sekolah Dasar. Jurnal Cakrawala Pendas, 4(1). https://doi.org/10.31949/jcp.v4i1.698.

Mulyati, S., \& Evendi, H. (2020). Pembelajaran Matematika Melalui Media Game Quizizz Untuk Meningkatkan Hasil Belajar Matematika Smp 2 Bojonegara. Gauss : Jurnal Pendidikan Matematika, 03(01), 64-73. https://doi.org/10.30656/gauss.v3i1.2127.

Nashiroh, P. K., Ekarini, F., \& Ristanto, R. D. (2020). Efektivitas Penerapan Model Pembelajaran Kooperatif Tipe Jigsaw Berbatuan Mind Map terhadap Kemampuan Pedagogik Mahasiswa Mata Kuliah Pengembangan Program Diklat. Jurnal Pendidikan Teknologi Dan Kejuruan, 17(1), 43. https://doi.org/10.23887/jptk-undiksha.v17i1.22906.

Oktarina, T. (2020). Media Pembelajaran Online Untuk Mendukung Belajar Pada Stebis Islam Darussalam. MATRIK: Jurnal Manajemen, Teknik Informatika Dan Rekayasa Komputer, 19(2), 329-338. https://doi.org/10.30812/matrik.v19i2.674.

Priatna, A., \& Setyarini, G. (2019). Pengaruh Model Pembelajaran Role Playing Terhadap Keterampilan Berbicara Siswa Kelas IV SD Pada Pembelajaran Bahasa Indonesia. Pendas: Jurnal Ilmiah Pendidikan Dasar, 07(07), 134-136. http://dx.doi.org/10.23969/jp.v4i2.2139.

Puspitorini, R., Prodjosantoso, A. K., Subali, B., \& Jumadi, J. (2014). Penggunaan Media Komik Dalam Pembelajaran Ipa Untuk Meningkatkan Motivasi Dan Hasil Belajar Kognitif Dan Afektif. Jurnal Cakrawala Pendidikan, 3(3), 413-420. https://doi.org/10.21831/cp.v3i3.2385.

Putri Ningrat, S., Tegeh, I. M., \& Sumantri, M. (2018). Kontribusi Gaya Belajar Dan Motivasi Belajar Terhadap Hasil Belajar Bahasa Indonesia. Jurnal Ilmiah Sekolah Dasar, 2(3), 257. https://doi.org/10.23887/jisd.v2i3.16140.

Putria, H., Maula, L. H., \& Uswatun, D. A. (2020). Analisis Proses pembelajaran Dalam Jaringan (DARING) Masa Pandemi COVID-19 pada Guru Sekolah Dasar. Jurnal Basicedu, 4(4), 861-872. https://doi.org/10.31004/basicedu.v4i4.460. 
Rahmat, A. S. (2017). Games Book sebagai Media Peningkatan Minat Baca pada Pembelajaran Bahasa Indonesia SD Kelas Tinggi. Indonesian Journal of Primary Education, 1(1), 27. https://doi.org/10.17509/ijpe.v1i1.7494.

Salsabila, U. H., Habiba, I. S., Amanah, I. L., Istiqomah, N. A., \& Difany, S. (2020). Pemanfaatan Aplikasi Quizizz Sebagai Media Pembelajaran Ditengah Pandemi Pada Siswa SMA. Jurnal Ilmiah Ilmu Terapan Universitas Jambi, 4(2), 163-173. https://doi.org/10.22437/jiituj.v4i2.11605.

Satrianingrum, A. P., \& Prasetyo, I. (2020). Persepsi Guru Dampak Pandemi Covid-19 terhadap Pelaksanaan Pembelajaran Daring di PAUD. Jurnal Obsesi : Jurnal Pendidikan Anak Usia Dini, 5(1), 633. https://doi.org/10.31004/obsesi.v5i1.574.

Setiawan, T. H., \& Aden. (2020). Efektifitas Penerapan Blended Learning Dalam Upaya Meningkatkan Kemampuan Akademik Mahasiswa Melalui Jejaring Schoology Di Masa Pandemi Covid-19. Jurnal $\begin{array}{llll}\text { Pembelajaran Matematika Inovatif } & \text { (JPMI), }\end{array}$ https: //doi.org/10.22460/jpmi.v3i5.493-506.

Suryani, E., \& Aman, A. (2019). Efektivitas pembelajaran IPS melalui implementasi metode jigsaw ditinjau dari aktivitas dan hasil belajar. Harmoni Sosial: Jurnal Pendidikan IPS, 6(1), 34-48. https://doi.org/10.21831/hsjpi.v6i1.17376.

Susilo, S. V. (2020). Penggunaan Media Pembelajaran Berbasis Audio Visual Untuk Meningkatkan Hasil Belajar Bahasa Indonesia Di Sekolah Dasar. Jurnal Cakrawala Pendas, 6(2). https://doi.org/10.31949/jcp.v6i2.2100.

Sutarto, S. (2017). Teori Kognitif dan Implikasinya Dalam Pembelajaran. Islamic Counseling: Jurnal Bimbingan Konseling Islam, 1(2), 1. https://doi.org/10.29240/jbk.v1i2.331.

Wahyudi, W., Rufiana, I. S., \& Nurhidayah, D. A. (2020). Quizizz: Alternatif Penilaian di Masa Pandemi Covid-19. Jurnal Ilmiah Soulmath: Jurnal Edukasi Pendidikan Matematika, 8(2), 95. https://doi.org/10.25139/smj.v8i2.3062.

Wahyuningtyas, R., \& Sulasmono, B. S. (2020). Pentingnya Media dalam Pembelajaran Guna Meningkatkan Hasil Belajar di Sekolah Dasar. Edukatif: Jurnal Ilmu Pendidikan, 2(1), 23-27. https://doi.org/10.31004/edukatif.v2i1.77.

Wibawa, R. P., Astuti, R. I., \& Pangestu, B. A. (2019). Smartphone-Based Application "quizizz" as a Learning Media. Dinamika Pendidikan, 14(2), 244-253. https://doi.org/10.15294/dp.v14i2.23359.

Wijayanti, R., Hermanto, D., \& Zainudin, Z. (2021). Efektivitas Penggunaan Aplikasi Quizizz Pada Matakuliah Matematika Sekolah Ditinjau dari Motivasi dan Hasil Belajar Mahasiswa. Jurnal $\begin{array}{llll}\text { Cendekia : Jurnal } \quad \text { Pendidikan } & \text { 347-356. }\end{array}$ https://doi.org/10.31004/cendekia.v5i1.470.

Wilson, A. (2020). Penerapan Metode Pembelajaran Daring (Online) melalui Aplikasi Berbasis Android saat Pandemi Global. SAP (Susunan Artikel Pendidikan), 5(1). https://doi.org/10.30998/sap.v5i1.6386. 